\title{
DIFFERENTIAL IMMUNOHISTOCHEMISTRY EXPRESSION OF VASCULAR ENDOTHELIAL GROWTH FACTOR BETWEEN RHIZOME TURMERIC AND BAY LEAF EXTRACTS IN WHITE MICE WITH HYPERLIPIDEMIA
}

\author{
Muttia Amalia, Maria Selvester Thadeus, Niniek Hardini \\ Faculty of Medicine UPN “VETERAN”, Jakarta
}

\begin{abstract}
Background: Atherosclerotic cardiovascular disease is the leading cause of death and disability in the world. Hyperlipidemia is the main feature of atherosclerotic cardiovascular disease. Amounts of spice including rhizome turmeric and bay leaf present in the diets vary by country, diets, worldwide, and this may have positive or negative effects on the initiation and development of atherosclerosis. This study aimed to examine the differential immunohistochemistry expression of vascular endothelial growth factor between rhizome turmeric and bay leaf extracts in white mice with hyperlipidemia.

Subjects and Method: This was a randomized controlled trial with pre and post test with control group design. A sample of 30 white male rats were given high-fat feed and randomly divided into 6 group: (1) negative control with CMC; (2) positive control with simvastatin drugs; (3) treatment with rhizome turmeric extract $200 \mathrm{mg} / \mathrm{kg} \mathrm{BW}$; (4) treatment with rhizome turmeric extract $400 \mathrm{mg} / \mathrm{kg} \mathrm{BW}$; (5) treatment with bay leaf extract $200 \mathrm{mg} / \mathrm{kgBW}$; (6) treatment with bay leaf extract $400 \mathrm{mg} / \mathrm{kgBW}$. The dependent variables were cholesterol and VEGF. The data cholesterol was measures 3 times: before and after was given of high fat feed, and after intervention The independent variables were rhizome turmeric extract and bay leaf extract. The data were analyzed by General Linear Model Repeated Measures.

Results: Simvastatin drugs and rhizome turmeric extract of 200 and of $400 \mathrm{mg} / \mathrm{BW}$ reduce cholesterol levels in group 2 (19.6\%), group 3 (17.3\%), and group 4 (15.4\%). The Mann-Whitney test showed there was mean differences between groups 1, 2, 3, and 4 . It was statistically significant $(\mathrm{p}=0.034)$. VEGF expresion decreased in group 2,3 , and 4 .

Conclusion: Simvastatin drugs and rhizome turmeric extract of 200 and of $400 \mathrm{mg} /$ BW are effective to reduce cholesterol and VEGF expression in white male rats.
\end{abstract}

Keywords: cholesterol, VEGF, rhizome turmeric, bay leaf.

Correspondence:

Muttia Amalia. Faculty of Medicine UPN “VETERAN”, Jakarta. Email: muttia.aw@gmail.com.

The $6^{\text {th }}$ International Conference on Public Health

Best Western Premier Hotel, Solo, Indonesia, October 23-24, 2019 | 350

https://doi.org/10.26911/the6thicph.05.15 